\title{
A STUDY ON THE MAGNITUDE OF HUMAN RESOURCE IN SUN AND RANBAXY MERGER
}

\author{
ANJALI DAISY $\mathbf{S}^{1 *}$, VIJAYABANU C ${ }^{2}$ \\ ${ }^{1}$ Department of MBA, Research Scholar, School of Management, Sastra University, Thanjavur, Tamil Nadu, India. ${ }^{2}$ Department of MBA, \\ Faculty, School of Management, Sastra University, Thanjavur, Tamil Nadu, India. Email: anjalidaisy2011@gmail.com
}

Received: 25 August 2016, Revised and Accepted: 29 September 2016

\section{ABSTRACT}

Sun Pharmaceutical is a trailblazer in Indian pharmaceutical sector, and one of the foremost competitors in the generic drug market sets its eye on Ranbaxy. Sun pharmacy which was established in 1983 listed from 1994 has its upper hand in product development. Ranbaxy was incorporated in 1973, and Daiichi Sankyo, a Japanese firm, got a controlling share from 2008. This amalgamation between Sun Pharmacy and Ranbaxy would get profitable transaction for the former. The process of the coalition was a cloak and dagger affair until April 6, 2014. Before mergers and acquisitions, a company has to create an urgency call among the employees which will result in better understanding of the whole scenario. The aspects are about how financial motives and non-financial motives play a major role in mergers. This case deals with the human resource issues and complexities faced by the two players in the same business.

Keywords: Merger, Acquisition, Change management, Human resource, Employee engagement, Corporate strategy.

(C) 2017 The Authors. Published by Innovare Academic Sciences Pvt Ltd. This is an open access article under the CC BY license (http://creativecommons. org/licenses/by/4. 0/) DOI: http://dx.doi.org/10.22159/ajpcr.2017.v10i1.14890

\section{INTRODUCTION}

The combination of Sun Pharmaceutical Company and Ranbaxy was expected to form the fifth largest drug-creating company within the world and therefore the largest India. Post merger, if Ranbaxy disappears from its current operations then the combined entity will extend upto 55 countries with 47 producing facilities. Daiichi Sankyo Inc., the previous owner of Ranbaxy, became the second largest investor in Sun Pharmaceutical Company and was to possess one representative on the company's board of administrators [1]

In today's competitive environment, there is a continuous effort by organizations to reduce cost and increase efficiency. One critical factor that organizations tend to ignore is investing in human capital. Sun Pharmacy realized that improving the skill and knowledge of employees can help them attain great cost reductions. The most successful organizations are able to build high-performance workforce. There is a definite link between employee engagement and organizational performance. If the management is able to identify and remove the roadblocks that decrease engagement, they can ensure better performance of both individual and organization [2].

Different parts of meeting up for a shared objective or a reason will result in high performance. This has been a repeating highlight for the worldwide pharmaceutical industry too. As weights on medication assembling, innovative work, and administrative perspectives have been on the ascent in view of the aggressive business environment in the most recent decade, the pharmaceutical business' overall development has achieved an immersion point [3].

Streets for development have got to be restricted as a result of declining remedies of marked medications and appearance of nonexclusive medication items. Further administrations of North America and Europe are compelled to press their social insurance spending plans to the bigger masses with financially savvy bland items.

\section{CASE ANALYSIS}

Marked medication results of the bigger pharmaceutical organizations face cost increments to conceal for the declining edges. Every one of these elements adds to the rising merger and procurement marvel in the pharmaceutical business [4].

- Horizontal mergers for business sector predominance; economies of scale

- Hybrid mergers for danger spreading, value cutting
- Cooperative energies, protective drivers

- Progress for world-sort administration and world Achievement

- Survival; vital mass

- Acquisition of cash, conceded assessments, and abundance

- Obligation capacity

- Exchange of resources

- Flexibility; influence.

- Better resource base to influence turnover

- Embrace most likely troublesome advancements

- Financial acquire and private vitality [5].

Examiners trust that merger and acquisitions are not ready to make the worth as coveted for the blended association as they are seen as wellspring of interruption for the continuous innovative work programs and in addition to other basic activities. In any case, the general advantages of the merger and securing methodology supersedes the disturbances. As indicated by the investigators, the mergers are basic for the long-term advantages of the pharmaceutical business and for their short and long haul survival. The worldwide pharmaceutical scene resembles a major sea where the bigger fish eats the littler fish for its survival. In an indistinguishable way, the biological system of the pharmaceutical business acts also.

In fact, the vast majority of the pharmaceutical organizations which have stayed in the Top 20 around 1995 and 2005 have been included in super mergers. Examiners characterize "super mergers" as arrangement esteem and size intersection $\$ 10$ billion. The genuine effect of mergers can be broke down from the years 1995 to 2011 where all arrangement size more prominent than $\$ 10$ billion can be considered as the strengths molding the pharmaceutical scene.

The sales chart of Sun Pharma shows that $60 \%$ of contribution from US and $23 \%$ of contribution from India and Ranbaxy's sales chart shows that $29 \%$ of share from US and 21\% from India which result in combined entity of $47 \%$ of share from US and $22 \%$ from India (Fig. 1).

Complexities faced by sun pharma post-merger

- Management capacity to manage large business

- Financial capability to pay for acquisition

- Strategic importance for long-term growth of a company

- The change management steps are mainly focused on: Need for urgency, forming an effective consortium, creating an action plan, communicating the action plan, delegating others to involve, planning for strategy (Fig. 2). 


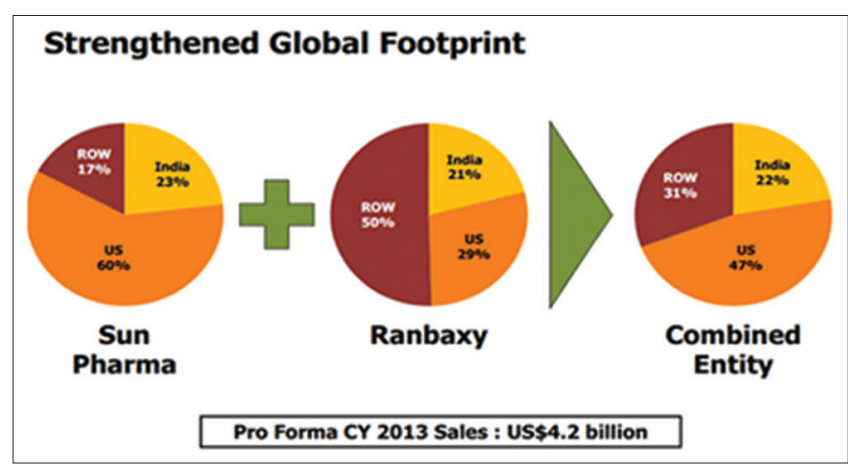

Fig. 1: Sales chart

\begin{tabular}{|l|}
\hline Need for urgency \\
\hline $\begin{array}{l}\text { Forming an effective } \\
\text { consortium }\end{array}$ \\
\hline $\begin{array}{l}\text { creating an action } \\
\text { plan }\end{array}$ \\
\hline $\begin{array}{l}\text { Communicating } \\
\text { the action plan }\end{array}$ \\
\hline $\begin{array}{l}\text { Delegating others } \\
\text { to involve }\end{array}$ \\
\hline $\begin{array}{l}\text { Planning for } \\
\text { strategy }\end{array}$ \\
\hline $\begin{array}{l}\text { Combining alterations } \\
\text { and make use of the } \\
\text { change }\end{array}$ \\
\hline $\begin{array}{l}\text { Applying New } \\
\text { styles }\end{array}$ \\
\hline
\end{tabular}

Fig. 2: Framework for change management

\section{HUMAN RESOURCE (HR) ISSUES}

\section{Practices and policies}

1. Making certain HR practices is must in a profound merger wherever we have a tendency to frame to vary each company. It will be useful for managers to understand a lot of issues regarding HR areas ought to amendment and what conditions contribute to vary them (Fig. 3). In the systematic and planned merger, it is believed that one firm will follow the practices and policies of the other. This could appear easy; nevertheless, there could also be conditions underneath that it is inappropriate to vary all practices. As an instance, if one firm acquires another in high value proposition there exists a huge and in depth brand potential and talent management practices.This will be a strategic choice for the company to retain dynamic policies.Retaining existing dynamic policies and practices. The motive of merger are either finance motive or non-finance motive (Fig 4).

2. In a design or natural process, merger could have the foremost important impact on staff as a result of the amendment is extremely important. In general, in the initial juncture of merger, it is assumed that future accomplishments of the companies and staff will also be better.

The conditions underneath the deal may fail for the subsequent.

- Sun Company needs to check the authority problems with Ranbaxy. The US authority has banned four of Ranbaxy's key plant that might last another year

- EBIDTA of Ranbaxy is extremely low around ten, means below trade standards and Sun Company needs to increase the EBIDTA

- Sun Company needs to increase the profitableness in rising markets like Romanian state wherever Ranbaxy is doing dangerous

- There is also a difficulty with the Competition Commission of Asian country as there are nearly 25 medicines which the combined entity holds over $400^{\text {th }}$ market share

- Ranbaxy has high debt on its record and Sun drug company has to begin with ways that to cut back the debt going forward. ThePharmaceutical deal which costs of 4 billion USD will limit sun pharma entering into specialty business for quite some time

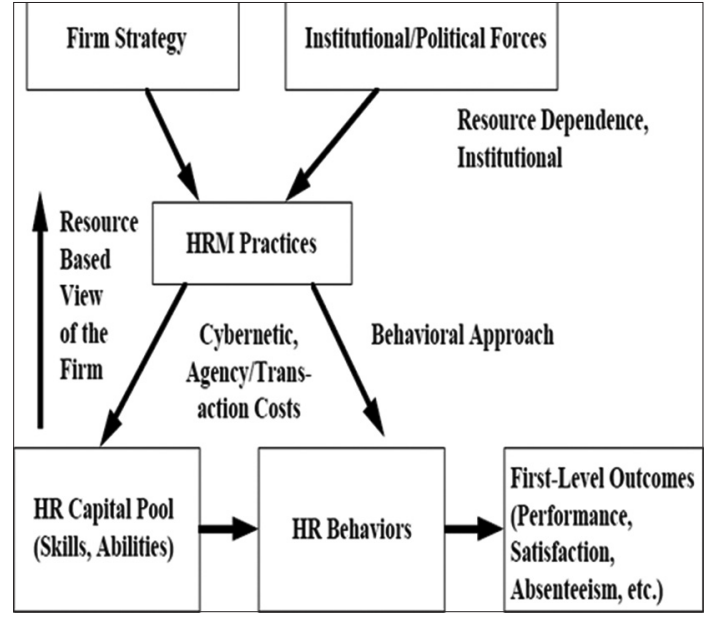

Fig. 3: Strategic model of HRM

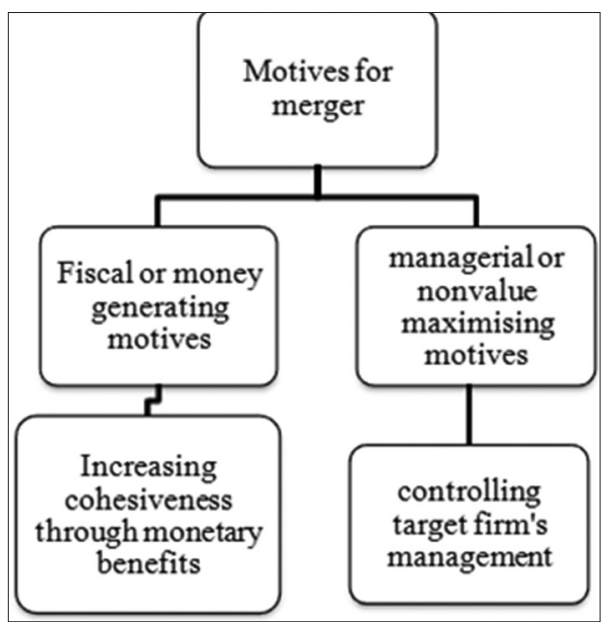

Fig. 4: Merger topology

- However, Sun Drug Company can have powerful task to shelve high overheads in Ranbaxy and improve gain in business

- It is extremely difficult to integrate 9000 selling personnel of each business

- It is clear that financial and HR dimensions in merger are equally important.

\section{CONCLUSION}

The Sun Pharmaceutical Company CEO Dilip Sanghvi is good in acquiring companies which are in critical situations and flourishes it to a different extent. Because of this, Daichii Sankyo is happy in this acquisition of Ranbaxy.

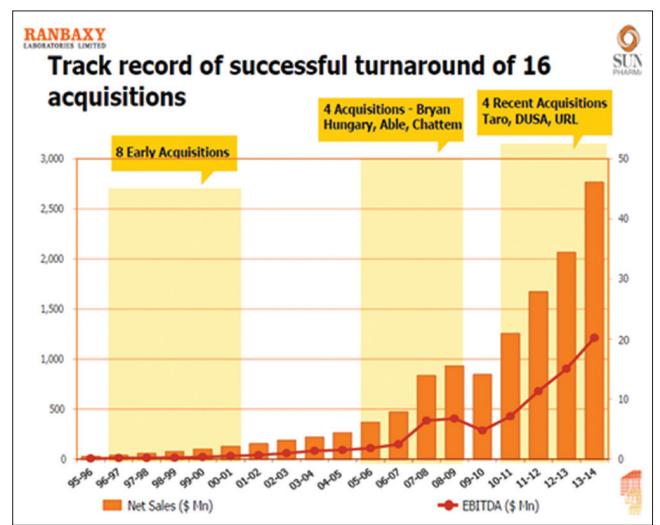

EXHIBIT-1 


\section{AQ9 REFERENCES}

1. Transcript Sun Pharma - Ranbaxy Merger Conference Call.pdf

2. Lindquist K. HR's role in mergers and acquisitions. Strateg HR Rev 2007;6(3):3.

3. Napier NK. Mergers and acquisitions, human resource issues and outcomes: A review and suggested typology. J Manage Stud 1989;26(3):271-90

4. Antila EM. The role of HR managers in international mergers and acquisitions: A multiple case study. Int J Hu Res Manage 2006;17:6, 999-1020.

5. Schweiger, DM, Ivancevich JM. Executives actions for managing human resources before and after acquisition. Acad Manage Exec $1987 ; 1(2): 127-37$.
6. Kotter JP. HBR's 10 must Reads on Change Management. Boston, MA: Harvard Business Review Press: 2011.

7. Truss C, Gratton L, Hope-Hailey V, Stiles P, Zaleska J. Paying the piper: Choice and constraint in changing HR functional roles. Hum Res Manage J 2002;12(2):39-63.

8. Legge K. Human resource management: A critical analysis'. In: Storey J, editor. New Perspectives in Human Resource Management. London: Routledge: 1989

9. Available from: http://www.investopedia.com/articles/ investing/022615/ranbaxy-and-sun-pharma- mega-indian-merger.asp. [Last accessed on 2016 Feb 18].

10. Available from: http://www.sunpharma.com/investors/archives/ sunpharma-ranbaxy-merger. [Last accessed on 2016 Mar 08].

Author Queries???

AQ8: Kindly check placement of unnumbered figure and also provide figure caption

AQ9: Kindly cite references 6-10 in the text part 